\title{
COMPONENTS OF PROCEDURE FOR ADOPTION OF PRELIMINARY DECISIONS ON CLASSIFICATION OF GOODS ACCORDING TO UCDACS
}

The article is devoted to the study of the procedure structure for the adoption of preliminary decisions on the classification of goods according to UCDACS. Implementation of the goods classification according to UCDACS to the actual movement of goods through the customs border by means of the adoption of preliminary decisions is an alternative option provided with the Customs Code of Ukraine.

The purpose of the article is the analysis of the legal regulation and structure of the procedure for the adoption of preliminary decisions on the classification of goods in accordance with UCDACS. Social relations that arise during the adoption of preliminary decisions on the classification of goods according to UCDACS are the object of the article.

The methodological basis of the study is a set of methods of scientific knowledge, in particular, system analysis in the researching of legal regulation of the procedure; formally legal for analysis and identification of problematic issues of law enforcement; methods of modeling, analysis and synthesis provided an opportunity to formulate proposals for amendments and additions to the provisions of the current customs legislation.

According to the results of the research, it was substantiated that the structure of the procedure for preliminary decisions on the classification of goods according to the UCDACS consists of stages and procedural actions. It is suggested that the structure of the procedure for making preliminary decisions regarding the classification of goods in accordance with the UCDACS consists of the following stages: starting of the procedure; consideration of the application and submitted documents; making a preliminary decision. Drawbacks in legal regulation of procedure for previous decisions on the classification of goods according to the UCDACSare founded and the ways for its overcoming are suggested.

Key words: classification of goods according to UCDACS, customs legislation, preliminary decisions, procedure, procedural action, stage, structure of procedure.

JEL Classification: K23.

\section{Anatolii MAKARENKO,} University of Customs and Finance, Ukraine

\section{Introduction}

Preliminary decisions in the customs case are well founded as the most effective means of simplifying trade procedures. It is precisely with preliminary decisions both in the current customs legislation and in the special literature the achievements of legal certainty are associated with the movement of goods through the customs border, the establishment of additional safeguards for foreign economic entities and revenue and fees, and, most importantly, ensuring the adaptation of the national customs legislation to international and European norms and standards.

We are sure that certain characteristics of preliminary decisions must necessarily be revealed during their adoption. In 
this regard, the study of the procedure for the adoption of preliminary decisions is the scientific interest.

Literature review. Questions of customs and tariff regulation, in particular their classification, were investigated in the works of I.G. Berezhnyuk, SG Voitova, O.P. Grebelnik, N.L. Huber'skaya, Ye.V. Dodin, S.V. Kivalov, T.O. Kolomoets, V.Ya. Nastyuk, D.V. Priyamachenko, V.V. Prokopenko, M.G. Shulga and many others. However, the procedure for the adoption of preliminary decisions on the classification of goods according to UCDACSwas not studied specially.

The purpose of the study is analysisof the legal regulation and structure of the procedure for the adoption of preliminary decisions on the classification of goods in accordance with UCDACS.

Research methods. The basis of the study was systematic analysis, with the help of which the legal regulation of the procedure for the adoption of preliminary decisions on the classification of goods according to UCDACS. Separate methods of scientific knowledge were also used, in particular formal-legal for analysis and identification of problematic issues of law enforcement; modeling and analysis and synthesis provided an opportunity to formulate a proposal for amendments and additions to the provisions of the current customs legislation.

\section{Results.}

According to i.1, p. 4 art. 23 of the Customs Code of Ukraine (CC of Ukraine) [4] preliminary decisions can be made on the classification of goods according to UCDACS. As it is known, all goods when they are declared are subject to classification (part 1 of art. 69 of the CC of Ukraine), therefore, in practice, a significant share of preliminary decisions is made precisely on the classification of goods according to UCDACS.

The procedure for adopting preliminary decisions on the classification of goods in accordance with UCDACS is based on the provisions of Art. 23 of the Customs Code of Ukraine and the Procedure of the work of the department of customs payments, customs clearance units of the customs authority and customs posts within the framework of the decision of the question of the classification of commodity units that are transported across the customs border of Ukraine, approved by the order of the Ministry of Finance of Ukraine of 30.05.2012 № 650 (hereinafter - Order 650) [5], in which some provisions of Section I and Section II are devoted to the preliminary decision.

It is generally accepted that the structure of the procedure consists of stages, stages and procedural actions. According to N.L. Huberska, these elements determine the structure and sequence of actions in the consideration and resolution of specific administrative cases [1, p. 77]. Mandatory elements in this case are the procedural steps and stages. In turn, the stages are distinguished, usually with more complex and lengthy procedures.

Accepting this and guiding $b$ the provisions of the current legislation, in particular art. 23 of the Customs Code of Ukraine [4] s. II of the Order No. 650 [5], we consider that the procedure for the adoption of preliminary decisions on the classification of goods according to the UCDACS consists of the following stages: 1) violation of the procedure; 2) consideration of appeal and submitted documentation; 3) making a preliminary decision.

Therefore, it is necessary to consider and provide a characteristic for each of these stages.

The stage of the procedurestarting originates from submission of a completed written application in accordance with the form given in Annex 1 to Order No. 650 [5] and the preparation of the necessary documents, including the development and certification of their copies. This is the first procedural action at this stage. 
It should be noted that the written application is filled in with a single item (article) of the goods (i. 4 s. II of the Order No. 650 [5]). That is, a separate preliminary decision is made for each item.

The following documents should be attached to the application: foreign economic agreement (contract) or other document used in international practice instead of contract (contract); technological schemes and technical requirements for the manufacture of goods (if any); drawings and photographs of the product (if any); certificates and permissions of authorized state bodies (if available); characteristics, catalogs and passport details of the manufacturer's product (if any); Certificate of origin of goods, marking labels, permits (if available); sample of the goods (if any).

From the list it is seen that the mandatory document is the foreign economic agreement, all others are provided in the case of their availability, and therefore depends on the specific product.

The submission of documents in the form of originals or copies is allowed. However, the provisions of Order No. 650 [5] do not provide for the need to certify copies of these documents, which is not in accordance with the general requirements of case management, in particular, the provisions of the national standard of Ukraine SSTU 4163-2003 (Uniform system of organizational and administrative documentation, requirements for the execution of documents) [3]. There is also no possibility to certify these copies by the body of incomes and fees during their adoption.

We propose to add the first sentence of the p. 2, it. 5, s. II of the Order 650 [5] after the word "copies" with the words "which are certified by the person submitting the application". There is also a requirement to translate into Ukrainian if they are drawn up in a language other than Ukrainian or other official languages of customs unions.

The next and final procedural action at this stage is the submission (sending) of the application and documents to the relevant body of revenues and fees. Allowed as a direct submission to the body of incomes and fees by its location, and posting using postal services, etc. Electronic submission is not currently provided for by current legislation.

Consequently, at this stage, the chosen procedural actions are committed by a person who wishes to obtain a preliminary decision on the classification of the goods in accordance with the UCDACS and are made obligatory.

At the stage of reviewing the application and the documents submitted, the first procedural action is registration of the application. It was established that an application is registered on the day of its actual receipt (p. 2, i. 6, s. Ilof the Order 650 [5]). Also, Order N 650 establishes the form for registration of applications for the adoption of preliminary decisions (Annex 2), however electronic registration is also possible [5].

At the same time, the Typical instruction for document management information in electronic form and organization of work with electronic documents in office work, electronic interagency exchange, approved by the Resolution of the Cabinet of Ministers of Ukraine dated January 17, 2018 No. 55 [2] anticipates that the electronic form is the main form of case management (p.1, i.2). Consequently, the provisions of the Order No. 650 [5] do not meet the requirements of this Instruction and need to be brought into conformity.

The timing of the adoption of the preliminary decision on the classification of goods in accordance with the UCDACS is precisely connected with the registration of the appeal by the body of incomes and fees, which according to part 5 of art. 23 of the Customs Code of Ukraine [4] is 30 days, with the possibility to be extended by no more than 15 days, that is reported to the 
person who had filed the application. Obviously, a similar provision is contained in i. 9, s. II of the Order No. 650 [5], the analysis of which should emphasize the positivity of sub-legislative regulation, aimed at overcoming the cornerstones of legislative regulation.

Thus, Order No. 650 specifies that it is a question of "calendar" days, which makes it impossible to interpret them as "working days", and also provides that the general term (30 calendar days) can be extended to the ending of the 30-day period with the indication of the reasons.

The next procedural action is consideration of the submitted documents for the adequacy of a preliminary decision, which verifies the actual compliance of the documents submitted to the mandatory submission and their general content.

Considering that according to p. 1 i.5s. II of the Order No. 650 [5] only the foreign economic contract (contract) or other document used in international practice instead of the contract must be provided, at checkingspecial attention is paid to the content of other applications.

In the case of failure to submit all necessary documents and information for the acceptance of the previous decision, the applicant's notification about the need to submit additional documents is made. In this procedural action, the applicant receives a written or electronic notification of the need to provide additional documents. This is an optional procedural action, which is performed in case of establishing the insufficiency of submitted documents for making a preliminary decision, based on the results of the preliminary procedural action.

It should be noted that the deduction of the term for the adoption of a preliminary decision begins with the date of the issuance of all necessary documents, therefore, with the commission of this optional procedural action, the period of the adoption of the preliminary decision is actually stopped.

At the same time, in accordance with i. 10, s. II of the Order No. 650, in the case of filling an application without the necessary part of the necessary documents and information for a preliminary decision to deduct the period of the acceptance of the preliminary decision begins from the date of submission of all the documents that were missing, is not in compliance with provisions of part 5, art. 23 of the Customs Code of Ukraine [4], according to which the period of acceptance of the preliminary decision on classification of goods according to UCDACS consist of 30 days from the day of submission of the corresponding appeal to the body of incomes and fees.

The relationship between the submission of "all necessary documents and information" and the calculation of this period of the Customs Code of Ukraine is not established, in contrast to preliminary decisions on the determination of the country of origin of goods, for which the Customs Code of Ukraine provides that the term of acceptance is no more than 150 days from the date of submission appropriate appeal to the body of incomes and fees, provided all the necessary information about goods [4].

Consequently, the given provision of the Order No. 650 does not find appropriate confirmation in the provisions of the Customs Code of Ukraine, and therefore contains a groundless restriction of the rights of the applicants, regarding the timing of consideration of the application for the adoption of a preliminary decision. In this regard, in order to bring the provisions of Order No. 650 in line with part 5 of art. 23 of the Customs Code of Ukraine, we propose the first sentence of i. 10, s. II of the Order No. 650 to exclude.

The next procedural action, which is necessarily performed, is the verification of the consideration of the application for an identical product by another body of incomes and fees. This action is in the course of verification of the fact that the applicant submitted an application for this product to other bodies of income and fees that were accepted by them for consideration. 
Such verification is carried out in accordance with i. 12, s. II of the Order No. 650 [5], with the help of the Unified Automated Information System (hereinafter referred to as the "UAIS").

The procedural action is to prepare the refusal to consider the appeal in the case of failure to provide all necessary documents or to establish the fact that the other body examines the revenues and fees of the applicant's application for an identical product. Therefore, this procedural action may also be carried out after the procedural action-the applicant's communication about the need to submit additional documents, in case if the requested documents will still not be provided.

The refusal to consider an appeal does not prevent a repeated application in case of elimination of the reason, which was the reason for refusal (p. 2, i. 11, s. II of the Order number 650 [5]). It is also an optional procedural act.

Before proceeding to the next procedural steps, it is worthwhile to focus on clarifying the ratio of "refusal to consider the appeal" and "refusal to make a preliminary decision", in connection with their simultaneous use in i. 11, s. II of the Order No. 650 [5].If the "refusal to consider the appeal" does not preclude a repeat referral in case of elimination of the reason for refusal, as indicated above, that is, the adoption of the preliminary decision is possible, but the applicant does not meet all the necessary requirements for this.

Thus, the "refusal to make a preliminary decision" makes it impossible to make a preliminary decision, and the reasons can not be eliminated, that is, it is not allowed to reapply on this issue.

Thus, the content of the a. 1 i. 11 s. II of the Order No. 650 [5], according to which "... the customs authority refuses to consider the application with the justification of the reasons which have become the basis for refusal to make a preliminary decision ...", unjustifiably combines "refusal to consideration of the appeal "and" refusal to make a preliminary decision ".

Therefore, we offera. 1 i. 11 s. II of the Order No. 650 [5] after the words "justification of the reasons" to read as follows: "which became the basis for such a refusal, with the return of samples and samples of the goods (in case of their submission)".

The next procedural action is the checking in the database of the UAIS of the availability of preliminary decisions on identical, or similar products to the information specified by the applicant in the application, the implementation of which is carried out using the software and information complex "Registry of preliminary decisions on the classification and coding of goods in the UCDACS" UAIS.

The last procedural action at this stage is the preparation of a refusal to issue a preliminary decision, which is carried out in case of establishing the fact of acceptance of the product of a preliminary decision, which has not been changed or canceled, or the presence of facts and conditions under which it was accepted remain unchanged, the preliminary decision is not provided (i.13 s. II of the Order No. 650 [5]). In this regard, this procedural action is also optional.

Consequently, at the stage of consideration of the application and the submitted documents, there are both mandatory and optional procedural acts committed by the incomes and fees authorities and those who wish to obtain a preliminary decision on the classification of the goods according to theUCDACS.

The final stage is the adoption of a preliminary decision. Structurally, this stage consists of such procedural actions.

The first procedural action, in the case of a positive review of the application and the documents submitted, is the execution of the preliminary decision. The preliminary decision on the form of the income and fee body is drawn up in the form provided in Annex 3 of the Order 
No. 650, taking into account the specified order of filling its graph (p. 24 s. II of the Order No. 650)[5]. The preliminary decision may contain annexes, in particular product images, their parameters, particular reference characteristics specified in it (graph 7), and a photograph of the product and / or its packaging is printed on its back side.

Making a preliminary decision to the Register of preliminary decisions on the classification and coding of goods in the UCDACSUAISis the next in the queue (an electronic copy of the preliminary decision together with the available photo product, in accordance with i. 14s. II of the Order No. 650 [5] shall be entered in the register). The term of this procedural action is one working day after the execution of the preliminary decision.

The next procedural action is the publication (referral) of the preliminary decision to the applicant. In accordance with i. $16 \mathrm{~s}$. II of the Order No. 650 [5], the original of the preliminary decision is issued (sent) to the applicant. Taking into account that the choice of the priority option for the applicant to obtain a preliminary decision (extradition or communication) remains unregulated, in practice the applicant indicates this in the application. In case of choosing a variant with a direct issuing of a preliminary decision, after the registration of the last the revenues and fees bodies inform the applicant.

At the same time, there are no requirements for forwarding the applicant's decision to the Order No. 650 [5], in particular, the type of postal item, the need to receive notification of the delivery of the item, etc. Such kind of departure must contain a description and be sent with the notification of delivery to the applicant, that is, a valuable letter.

The last procedural action is the disclosure of information about the preliminary decision. This is done in accordance with p. 12 of art. 23 of the Customs Code of Ukraine [4], according to which preliminary decisions, with the exception of confidential information, are publicly available and can be made public. From the analysis of this provision, we consider it necessary to focus attention on the following. First, in this case, it is not about "publishing a preliminary decision", but about "disclosure of information about a preliminary decision", that is, a textmade prior decision is not made public.

Second, the central body (the State Fiscal Service of Ukraine) ensures such disclosure, it is confirmed on the official portal of the State Fiscal Service of Ukraine [6], which contains information about the preliminary decisions on the classification of goods according to UCDACS since 2015. Third, the period during which such disclosure is made is not specified neither in $p$. 12 of the art. 23 of the Customs Code of Ukraine [4] nor in the Order No. 650 [5], that allows the State Fiscal Service of Ukraine to solve this issue independently, hence there is a risk of non-compliance with this provision.

Fourthly, there is also no disclosure procedure, in the case of electronic disclosure of information about preliminary decisions or their printing, for example in the official publication of the State fiscal service of Ukraine. However, as it is noted above, information is currently being published on the official portal. In the fifth, the information can be confidential only about the goods and the applicant can inform it in the application for the adoption of a preliminary decision, in accordance with p. 1 i. 6 of s. II of the Order No. 650 [5]. The body of income and fees, taking into account the existence of such a notification by the applicant, performs it without interfering in this matter.

Consequently, at the stage of the adoption of the preliminary decision, each procedural act is carried out by the income and fee bodies and is obligatory. 


\section{Conclusions}

Thus, the structure of the procedure for the adoption of preliminary decisions on classification of goods according to UCDACS can be presented through the following stages:

1. The stage of violation of the procedure consists of the following procedural steps:

1) filling in the written application and preparation of documents;

2) submission (sending) of applications and documents to the relevant body of incomes and fees.

2. The stage of consideration of the application and submitted documents consists of the following procedural steps:

1) registration of application;

2) verification of the adequacy of the submitted documentation for the adoption of a preliminary decision;

3) notification of the applicant about the need to submit additional documents (optional);

4) verification of the consideration of an application for an identical product by another body of income and fees;

5) preparation of the refusal to consider the appeal (is optional);

6) verification in the database of the UAIS of the existence of preliminary decisions on identical, similar or similar goods to the information specified in the applicant in the application;

7) preparation of refusal to issue a preliminary decision (optional).

3. The preliminary decision-making process consists of the following procedural steps:

1) execution of the preliminary decision;

2) making a preliminary decision to the Register of preliminary decisions on the classification and coding of goods in the UCDACSUAIS;

3) publication (referral) of the preliminary decision to the applicant

4) disclosure of information about the preliminary decision.

According to the results of the study, amendments and additions to the Order No. 650 were proposed:

- add the first sentence of p. 2 i. 5 s. II after the word "copies" with the words "which are certified by the person submitting the application";

- p. 1 i. 11s.II after the words "justification of the reasons" read as follows: "which became the basis for such a refusal, with the return of samples and samples of the goods (in case of their submission)";

- in i. $11 \mathrm{~s}$. II to delimit the "refusal to consider the appeal" (in case of establishing the discrepancy between the application and the submitted documents to the established requirements, does not prevent the repeated application on condition of elimination of reasons) and "refusal to make a preliminary decision" (in case of impossibility to eliminate reasons and does not allow to re-apply);

-i. $15 \mathrm{~s}$. II supplement by the period of the publication of information about the preliminary decisions made.

\section{References:}

1. Guberskaja N. L. Ponjatie i struktura administrativnoj procedury. Visnik Mariupol's'kogo derzhavnogo universitetu. Serija: Pravo. 2014. Vip. 7. S. 76-82.

2. Dejaki pytannja dokumentuvannja upravlinsjkoj idijaljnosti: postanova Kabinetu Ministriv Ukrajiny vid 17.01.2018 r. № 55 / Kabinet Ministriv Ukrajiny. Oficijnyj visnyk Ukrajiny. 2018. № 23. St. 770).

3. DSTU 4163-2003. Unifikovanasystema orghanizacijno-rozporjadchoji dokumentaciji. Vymoghy do oformljuvannja dokumentiv: nakaz Derzhavnogho komitetu Ukrajiny $\mathrm{z}$ py- 
tanj tekhnichnogho reghuljuvannja ta spozhyvchoji polityky vid 07.04.2003 № 55. URL: http://zakon.rada.gov.ua/rada/show/v0055609-03 (datazvernennja 23.11.2018 r.).

4. Mytnyj kodeks Ukrajiny vid 13 bereznja 2012 r. \# 4495-VI / VerkhovnaRadaUkrajiny. VidomostiVerkhovnojiRadyUkrajiny. 2012. № 44-45, № 46-47, № 48. St. 552.

5. Pro zatverdzhennja Porjadku roboty viddilu mytnykh platezhiv, pidrozdilu mytnogho oformlennja mytnogho orghanu ta mytnogho postapry vyrishenni pytanj klasyfikaciji tovariv, shho peremishhuju tjsjacherezmytnyj kordon Ukrajiny: nakaz Ministerstva finansiv Ukrajiny vid 30.05.2012 r. № 650 / Ministerstvo finansiv Ukrajiny. Oficijnyj visnyk Ukrajiny. 2012. № 64. St. 2628.

6. Rejestr poperednikh rishenj shhodo klasyfikaciji ta koduvannja tovaru v UKTZED: oficijnyj portal Derzhavnoji fiskaljnoji sluzhby Ukrajiny. URL: http://sfs.gov.ua/baneryi/mitne-oformlennya/ subektam-zed/klasifikatsiya-tovariv/628 35.html (datazvernennja 23.11.2018 r.

\title{
СКЛАДОВІ ПРОЦЕДУРИ ПРИЙНЯТТЯ ПОПЕРЕДНІХ РІШЕНЬ

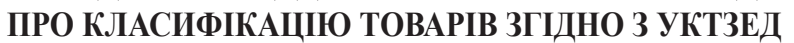

\author{
Анатолій МАКАРЕНКО, \\ Університет митної справи та фінансів, Украӥна
}

Статтю присвячено дослідженню структури процедури прийняття попередніх рішень про класифікацію товарів згідно з УКТЗЕД. Здійснення класифікаиії товарів згідно з УКТЗЕД до фактичного переміщення товарів через митний кордон шляхом прийняття попередніх рімень $\epsilon$ альтернативним варіантом, передбаченим Митним кодексом України.

Метою статті є аналіз правового регулювання та структури процедури прийняття попередніх рімень щзодо класифікації товарів відповідно до УКТЗЕД.

Об'єктом статті є суспільні відносини, які виникають під час прийняття попередніх рішень про класифікацію товарів згідно з УКТЗЕД.

Методологічну основу дослідження становить сукупність методів наукового пізнання, зокрема системний аналіз при висвітленні правового регулювання процедури; формально-юридичний для аналізу та з'ясування проблемних питань правозастосування; моделювання і аналізу та синтезу надали змогу сформулювати пропозииї щуодо внесення змін $і$ доповнень до положень чинного митного законодавства.

За результатами проведеного дослідження обтрунтовано, щзо структура процедури попередніх рішень про класифікацію товарів згідно з УКТЗЕД складається зі стадій та процедурних дій. Запропоновано, щзо структура процедури прийняття попередніх рімень щзодо класифікації товарів відповідно до УКТЗЕД складається з наступних стадій: порушення процедури; розгляд звернення та поданих документів; прийняття попереднього рішення. Доведено, щзо процедурні дії с обов'язковими та факультативними, вчиняються і органами доходів $i$ зборів, $i$ заявниками. Виявлено недоліки та прогалини в правовому регулюванні проиедури прийняття попередніх рімень щцодо класифікачії товарів відповідно до УКТЗЕД та запропоновано шляхи їх подолання іусунення.

Ключові слова: класифікація товарів згідно з УКТЗЕД, митне законодавство, попередні рішення, процедура, процедурна дія, стадія, структура процедури. 